\title{
The Blur of History: Student Protest and Photographic Clarity in South African Universities, 2015-2016
}

\author{
PATRICIA HAYES \\ SARChI Chair in Visual History and Theory, Centre for Humanities Research, \\ University of the Western Cape
}

I have three points I would like to put forward - about strong photographs, about clarity and about blur. I also have a number of photographs dating from October 2015 at the University of the Western Cape that will be planted through the text as the argument unfolds. ${ }^{1}$

\section{Strong photos}

My first point concerns strong photos. In recent debates about photographic archives and the idea of nation, Elizabeth Edwards argued that certain nations have strong photographs that speak to their nation-ness, or the process through which they became a nation. They offer 'strong history.' It is frequently pointed out how South Africa in particular has a rich and dense photographic archive of the anti-apartheid struggle, and that particular photographs took on iconic status during that time and have continued to shape the memory and meaning of how South Africa came into being. Thus, at the opening of the vast EyeAfrica exhibition at the Cape Town castle in 1998, curated by Revue Noire, the European ambassador who opened the exhibition stated in his speech that the entire world knew the South African struggle through its photographs, most notably Sam Nzima’s photograph of Hector Pieterson from 1976. As this exhibition was an attempt to launch a different kind of imagery from across the continent and more innovative recent South African work, this homogenising remark was not well received by everyone. Despite numerous critics and scholars who have sought to nuance or even reject the documentary decades leading up to South Africa's transition to the post anti-apartheid, ${ }^{3}$ a number of strong tropes still operate for an older generation in relation to a global perception of South African history through photographs.

Such tropes were efficacious in arousing widespread support and solidarity for different aspects of organisation, opposition, protest, fund raising, withdrawal of

All photographs, unless otherwise stated, are by the author.

2 Elizabeth Edwards, 'Photographs as Strong History' in Costanza Caraffa and Tiziana Serena, eds., Photo Archives and the Idea of Nation (Berlin: De Gruyter, 2015), 321-329.

3 Scholarship that has sought to bring more nuanced analyses to South African documentary photography is wide ranging and includes Patricia Hayes, 'The Form of the Norm: Shades of Gender in South African Photography of the 1980s', Social Dynamics, 37(2) (2011), 263-277; Patricia Hayes, 'The Colour of History: Photography and the Public Sphere in Southern Africa' in Sanil V. and Divya Dwivedi, eds., The Public Sphere from outside the West (London: Bloomsbury, 2015), 147-163; Okwui Enwezor and Rory Bester, eds., Rise and Fall of Apartheid: Photography and the Bureaucracy of Everyday Life (New York: International Centre of Photography, 2012). 


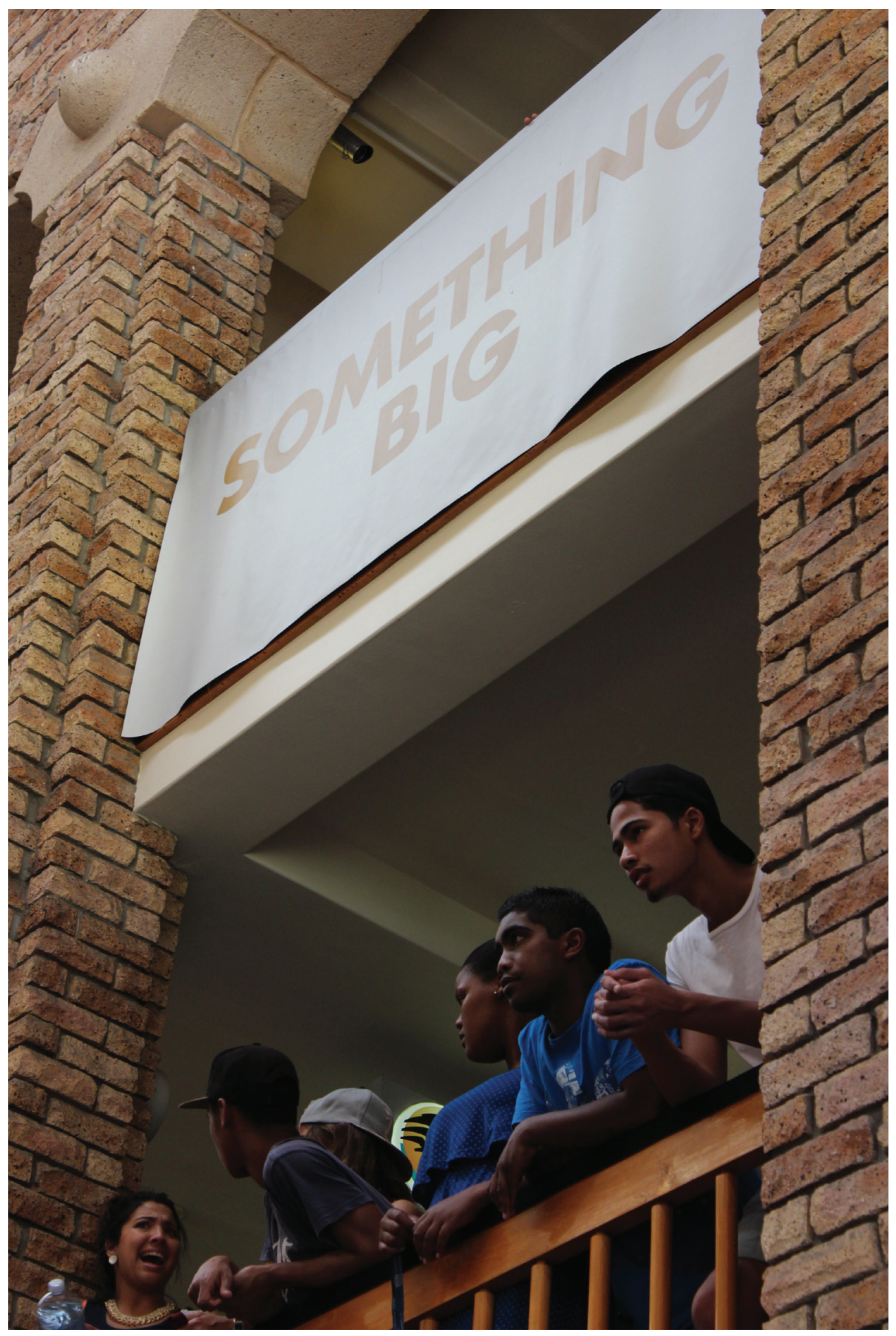

Figure 1 


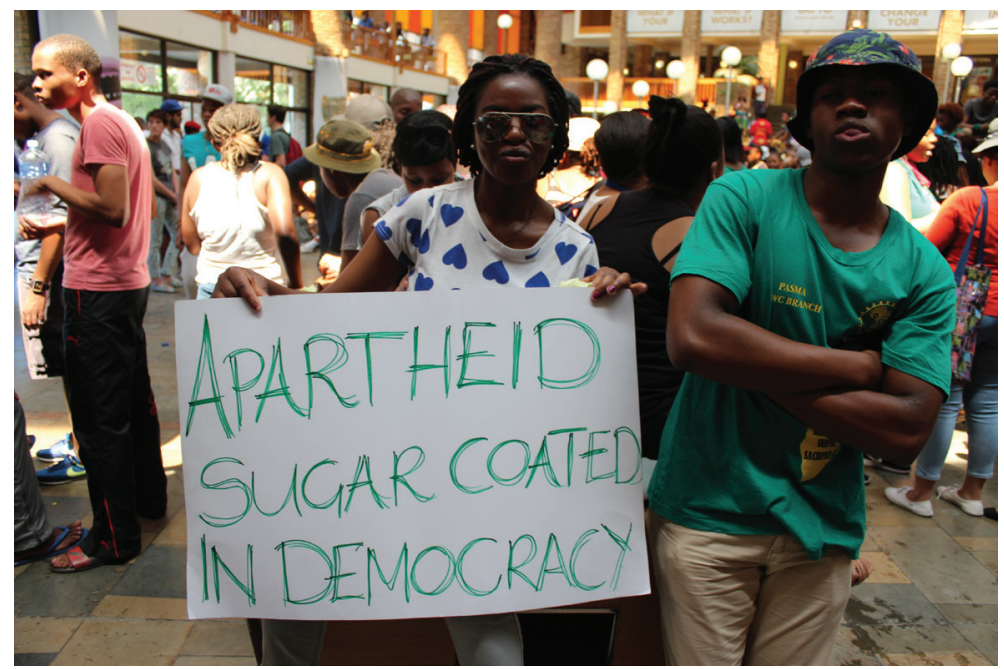

Figure 2

investment and more. ${ }^{4}$ Santu Mofokeng, for instance, argued that photographs of 'white cops beating up black kids', especially if the former were plural and the latter singular, would be taken up immediately by the international press. ${ }^{5}$

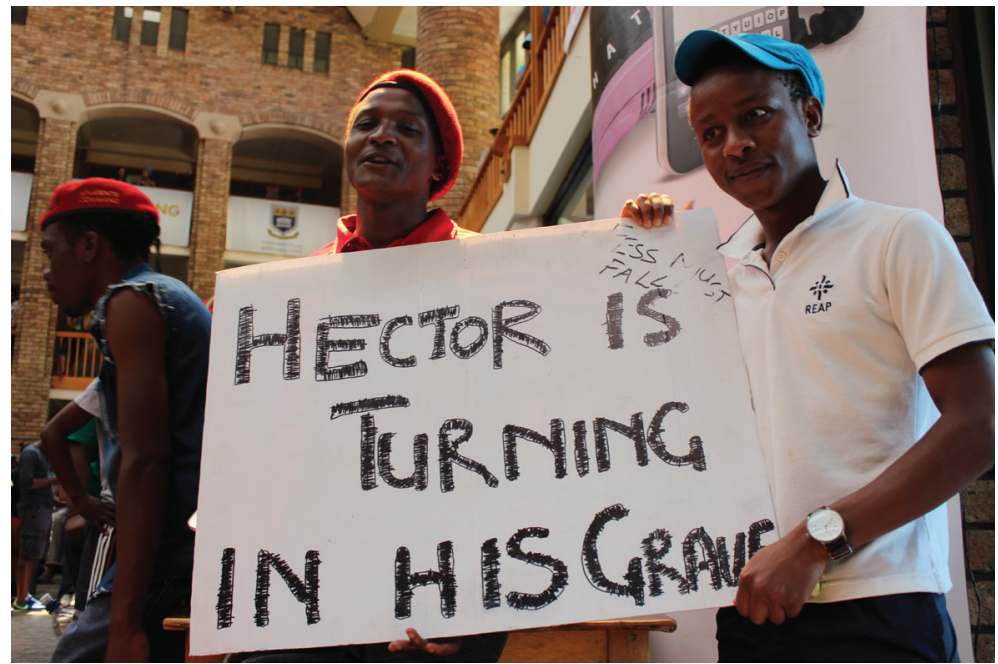

Figure 3

Nzima's single photographic print of Hector Pieterson made a very strong imprint around children, innocence, martyrdom, affliction and mourning that has had an extraordinary intermedial life since the end of apartheid. The real-life situations depicted by such photographs are one thing, registering abuse and injustice. This

See Patricia Hayes, 'Photographic Publics and Photographic Desires in 1980s South Africa', Photographies, 10(3) (2017), 314.

See Patricia Hayes, 'Santu Mofokeng, Photographs: “The Violence Is in the Knowing”, History \& Theory, 48(4) (2009), 39. 


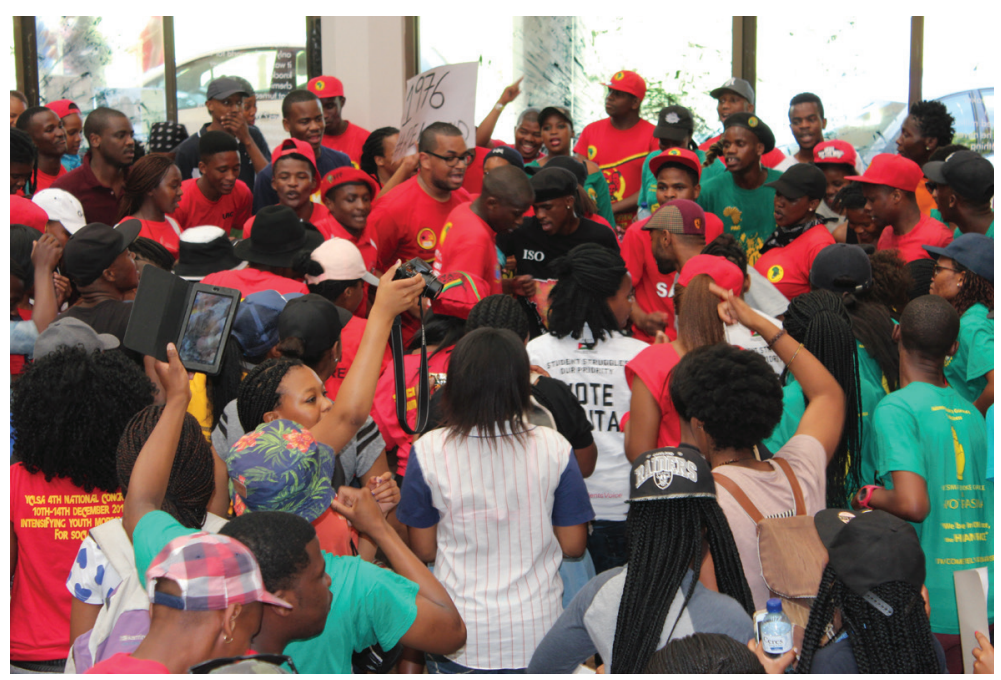

Figure 4

is not in dispute. However, through mass circulation practices, the asymmetries of power central to the kinds of images mentioned so far start to have effects rather like abolitionist iconography from the early nineteenth century, where victimised status (that is, receiving violence instead of doing violence) constructs worthy recipients of the viewer's support. There are other tropes that are more subtle: figures that take on Christ-like qualities or recall the crucifixion, in which guise Desmond Tutu sometimes appears. ${ }^{6}$ By drawing on Christian iconography, the reasonable, reasoning and heroic black man is humanised for audiences, especially in the global North. Other strong pictures that 'stick' include pictures of protest, of unity, in the march, the demonstration or the funeral.

\section{Clarity}

If these make up what Edwards calls 'strong' photos, we have so far spoken only about their content during a 'time of violence', as one Afrapix member put it. Afrapix was a photographers' collective operating from 1982 to $1992 .^{7}$ But there is another aspect to consider, and that is their clarity. By clarity I am referring not only to composition that provides information - in which we could include placards and T-shirt messages that explain the purpose of a march or demonstration, obviating the need for a caption and allowing the photograph to travel successfully anywhere with its message intact.

Clarity also refers to sharpness and exactness of focus, lined up precisely and built into the camera sights so as to work with lens manufacture. It may seem a very obvious point to make, but this aspect of clarity is part of very naturalised discourses Town: Umuzi Random House, 2010), 55; Gille de Vlieg's photograph in Tillman Hill and Alex Harris, eds., Beyond the Barricades: Popular Resistance in South Africa (New York: Aperture, 1989), 81.

7 On Afrapix, see David L. Krantz, 'Politics and Photography in Apartheid South Africa', History of Photography, 32(4) (2008), 290-300. 


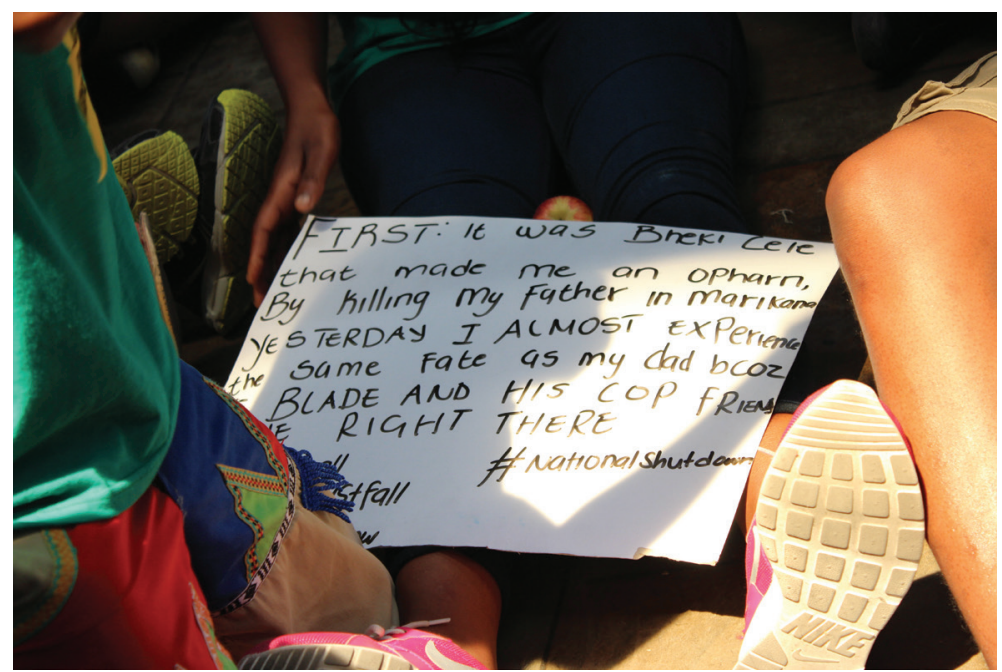

Figure 5

around the photographic medium. It is worth digging into some of the features that are masked by this naturalisation. The term 'focus' has an interesting etymology, derived from the Latin for hearth. According to Lindsay Smith,

Etymology incorporates the origins of photography in fire (light), as in the optical sense of a 'burning point of a lens or mirror', and in the meaning of centredness, implied in the centring function of hearth, and by extension, in the centring function of photography. ${ }^{8}$

'Focus' as a term shifted from its theatrical definition as the 'best illuminated part of the stage' to the 'best articulated part of a photographic image.'

But there is more. In terms of the lens, says Smith, focus is 'the power of giving a "sharp" image of objects not in the same plane, now usually expressed as a distance, and used as a synonym of "depth of field"'. Thus, focus is that which confers intelligibility upon objects, 'in spite of their planar disparity.' ${ }^{10}$ The implications in fact go very far.

From the beginning, the photographic definition of focus was made to serve existing systems of visual representation, and in particular to conspire with the dominance of geometrical perspective, thus further confirming the sovereignty of the latter in various media. In one fundamental and immediate sense, photography could appear to guarantee the continued ubiquity of

\footnotetext{
8 Lindsay Smith, The Politics of Focus: Women, Children, and Nineteenth Century Photography (Manchester: Manchester University Press, 1998), 16.

9 Ibid.

10 Ibid.
} 
geometrical accounts of space by seeming to represent geometrical spatial mapping in the greatest degree of verisimilitude experienced in visual perception up to that time. ${ }^{11}$

The development of the capacity of the photographic lens to record depth of field thus supports a specific system of representing space, whose ubiquity, argues Smith, was 'desired'. The system hinges on the 'Cartesian duality of vantage-point and vanishing-point'. This implies a distribution of 'the elements of a composition in such a way as to allow the eye the recessional register (distance) necessary to read the subject depicted in the manner of a projection. ${ }^{12}$ Even in the nineteenth century, some questioned why these qualities should be privileged over other approaches, where geometrical accuracy underpinned the belief in photography as the 'sovereign realist mode' and was equated with mastery.

Built into the history of photography, then, are a number of features that are often taken for granted. The centrality of focus implies parity across different planes, the ubiquity of a certain kind of perspectivalism, and the means to measure what falls within or outside this state. If these requirements for a centralising focus with its depth of field were not observed,

not only was there an assault on the integrity of the photographic process as coterminous with geometrical perspective, but a questioning of those qualities of enlightenment and rationalism, and of all that such a perspectival system stood for. ${ }^{13}$

These histories feed into a photographic discourse of realism that underpins the genre of documentary which occupies a special place in South Africa from the 1960 s to the 1980s. On the surface, its 'legitimising accuracy' presents information about identities and situations, providing a basis for positivist (and some like Smith would say masculinist) ${ }^{14}$ visual evidence which can be used both against, and by, political activists. Clarity is also what the state relies upon in graduated degrees for surveillance, for police footage, ID photographs. A number of Afrapix photographers also refer to the state's use of photographic and filmic documentation in the media to argue its case for repression. ${ }^{15}$ Progressive documentary photographers were no less invested in these stakes in order to counter the versions of events put out by the state and render their own versions. Thus visual truth must be answered by visual truth.

With the digital turn and automatic settings on a wide range of cameras and cellphones, sharp focus and clarity are provided for users who today enjoy guaranteed

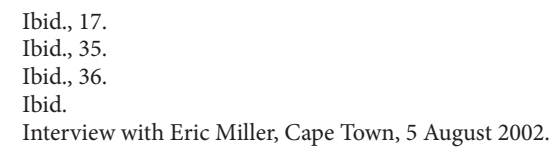




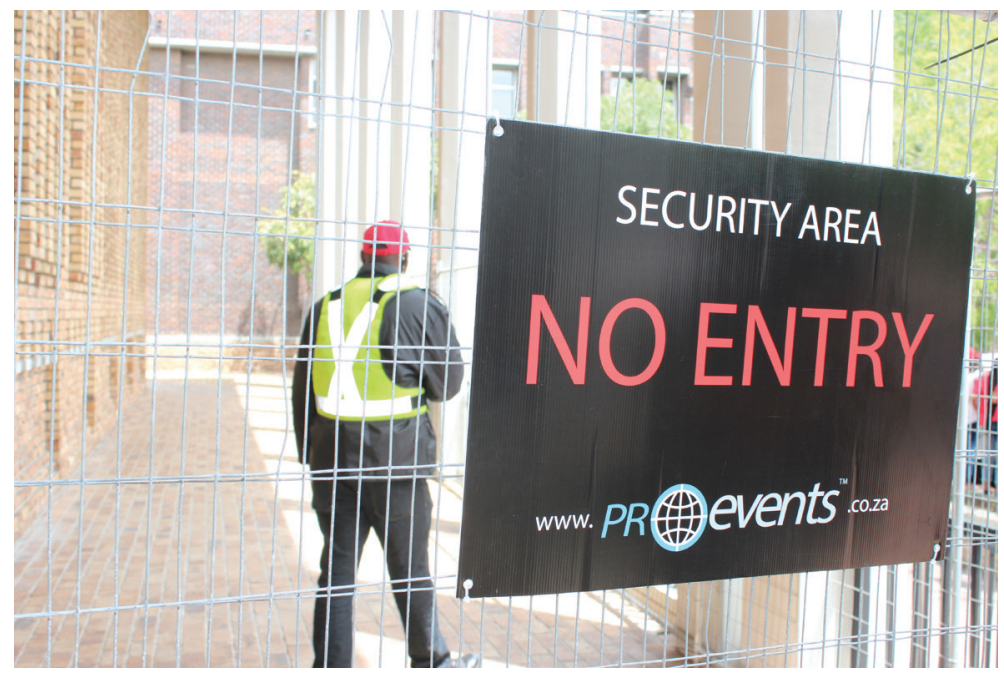

Figure 6

quality of photographic production that is then available on screen digitally and can be quickly transferred to social and other media. For those who turned to 'documenting' the events of October 2015 (and there were many), scenes and subjects were lined up with a clarity and sharpness that made this movement and wave of activity with all its encounters and tableaux visible in particular ways, related to the ways in which camera and lens manufacture determine certain modes of distributing the sensible, that is, how we see and sense things. ${ }^{16}$ Because this is usually automatic, and because it is allied to accelerated mobility of transfer and download for sharing and viewing, such programming features are hardly noticed. Automatic clarity becomes axiomatic. While almost entirely photographed in colour, this wave of photography shared certain features with earlier kinds of documentary realism. Photographs or video footage portraying police action against students, mostly outside campus, and security presences inside campus, aroused strong reactions that many from the older generation likened to the 1980s.

Some issues about the aesthetic moments and choices, of both students and nonstudents in this campus scenography, deserve further consideration. There are also larger questions about visibility itself, and when it is desirable or not.

I have been seeding my own photographs from October through this text thus far, from particular dates in the first week of the FeesMustFall campaign at the University of the Western Cape (UWC). There is much to debate here, but what I would like to point to, in particular, are the ways in which students in this group appear friendly to cameras, were using cameras and even self-consciously presenting themselves to cameras, mainly in the university Student Centre. Many students wrote slogans, aphorisms and longer autobiographical texts that were designed to be seen widely, in person and on screen. 


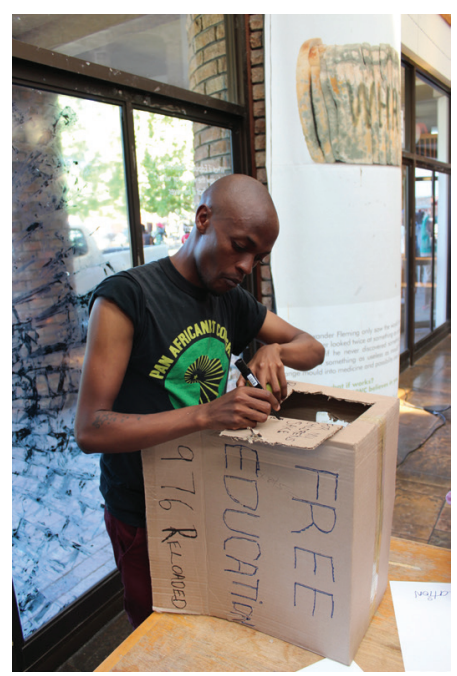

Figure 7

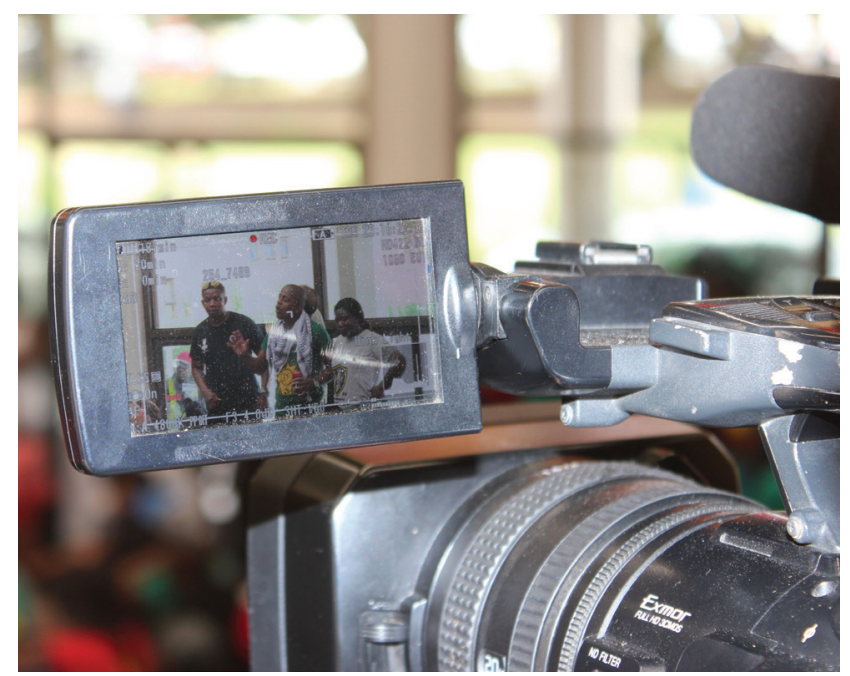

Figure 8

Speeches and viewpoint presentations were covered by all media.

Food donations and organisation were also open to the camera in the initial days. This period of visibility, however, started to transform in the next week, with tensions increasing around security presence, lack of dialogue, efforts towards mediation - with the result that food donors, for example, now wanted to remain anonymous, and I deleted my own photograph of a group of male protestors en route to investigate alleged abuse by security personnel at student residences on campus. While WhatsApp groups and social media had been running continuously alongside images appearing on different media, now the stakes of visibility changed and textual communication predominated.

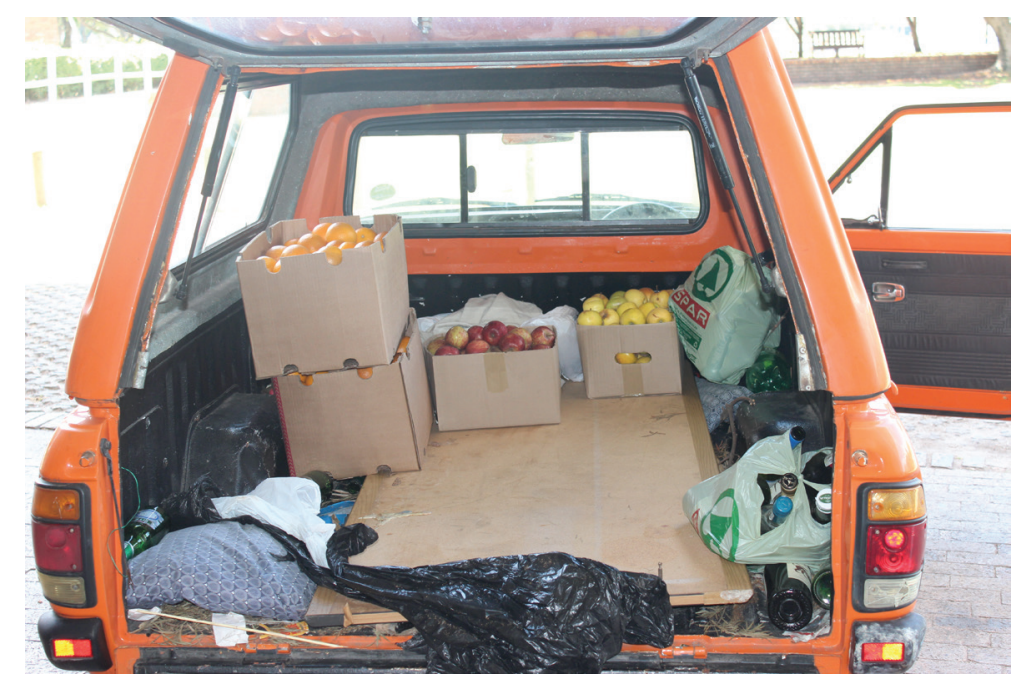

Figure 9 


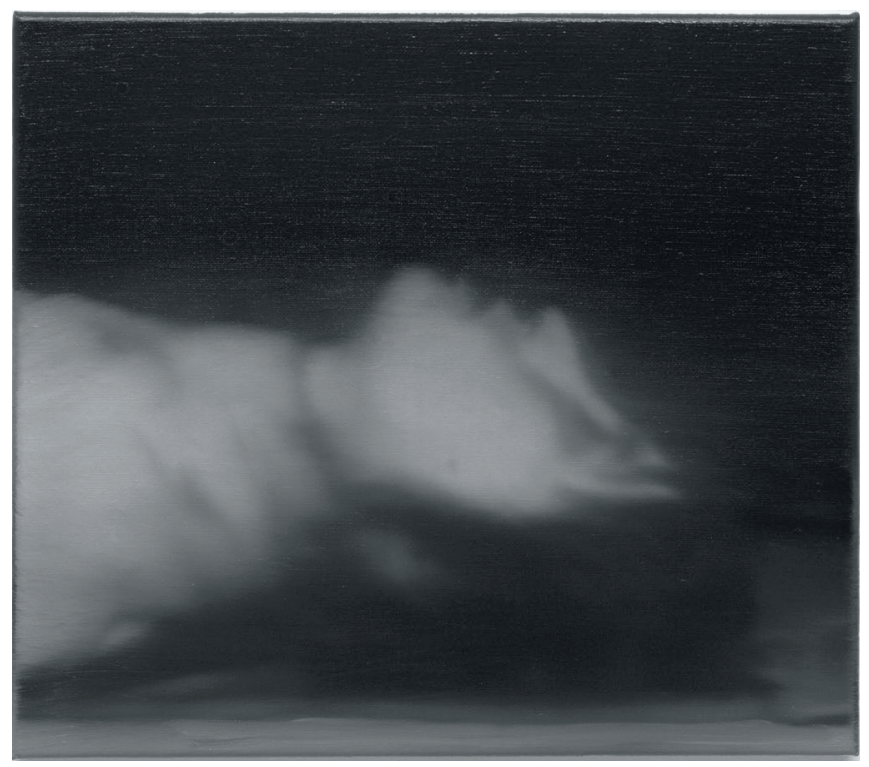

Figure 10. Gerhard Richter, Dead (1988)

\section{The blur}

The third point I want to raise in this brief essay relates to what I call the blur. I evoke the blur because it has a bearing on aesthetic choices, and as I have suggested, most contemporary modes of taking photographs have predetermined settings that push users towards clarity and sharpness and, by inference, an impression of narrative and even historical clarity. Given the bias towards the perspectival organisation of space in photography, it is important to bear in mind the 'apparent substitution of a seamless visual whole for what was once a composite of sensory perceptions and representations. ${ }^{17}$

The Gerhard Richter Stammheim Cycle or 18 October 1977, also known as part of the German Autumn series, might be useful to think with here. The cycle is a series of monochrome paintings of photographs of the bodies and prison cells of the Red Army Faction (RAF) members in Stammheim high-security prison, who were variously 'found' dead or dying, three shot and one hanged. One member survived. According to Allan Feldman, the imputed motive for mass suicide was the alleged precedent set by Ulrike Meinhoff the year before, when she hanged herself in her cell. ${ }^{18}$

Many unresolved questions remain, not least concerning those who allegedly shot themselves, in which case how was a gun smuggled into such a high-security facility?

Richter based his paintings on crime-scene photographs released to the media, and also drew on progressive photographic archives from the 1970s. As Feldman puts it,

17 Smith, The Politics of Focus, 62

18 Allan Feldman, Archives of the Insensible: Of War, Photopolitics, and Dead Memory (Chicago, IL: University of Chicago Press, 2015). 


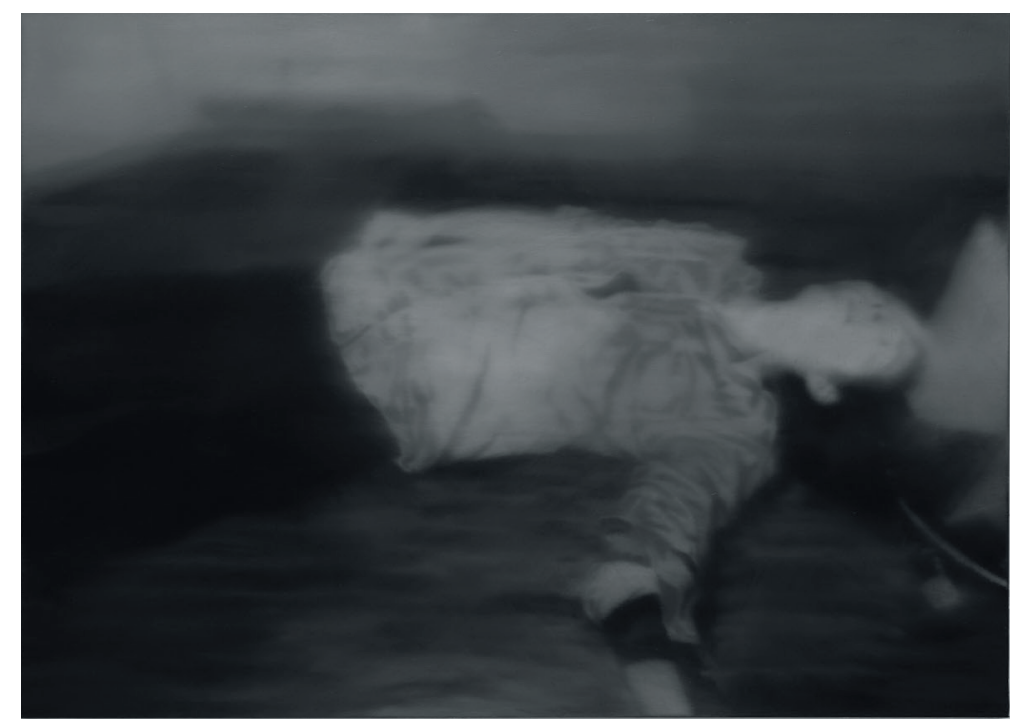

Figure 11. Gerhard Richter, Man Shot Down (1988)

the photo-paintings of the RAF are all notable for the juxtaposition of a certain photographic fidelity or mimicry with an interruptive blotting or blurring brushwork that renders the images hazy and out of focus (from the perspective of realism) in such a manner as to question the very historical possibility of proper focus and depth of field. ${ }^{19}$

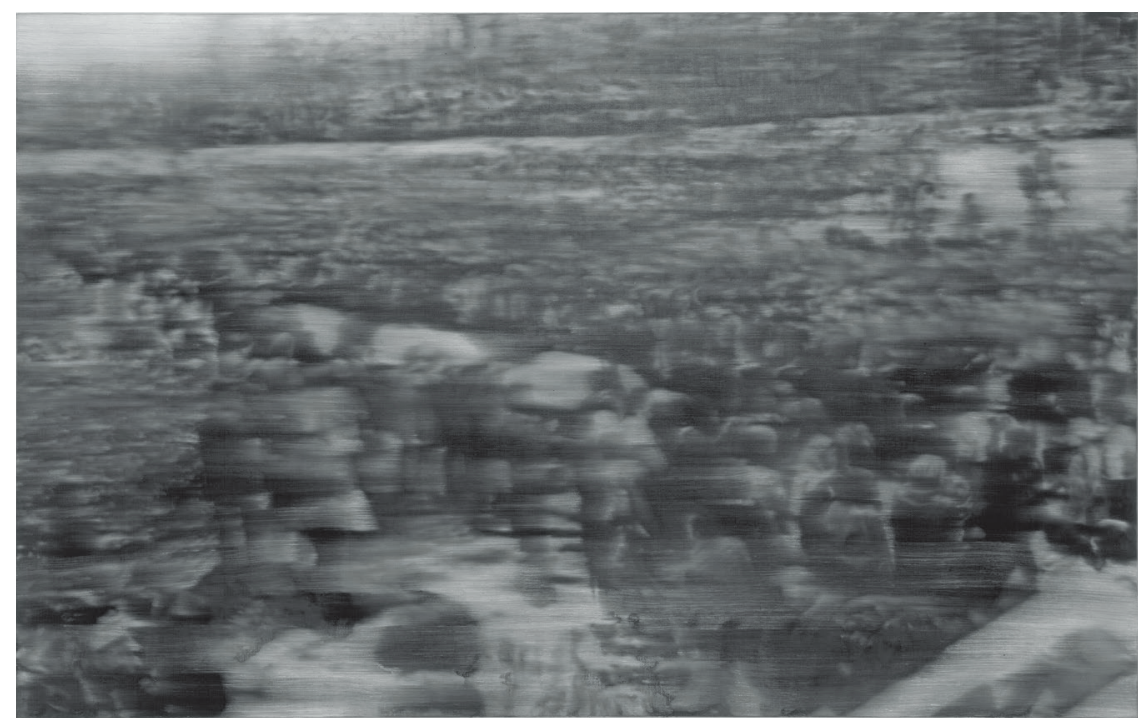

Figure 12. Gerhard Richter, Funeral (1988) 
The series includes the funeral of Andreas Baader, Gudrun Ensslin and Jan-Carl Raspe, attended by several thousand supporters and several thousand heavily armed policemen. Richter himself describes them as follows: 'All the pictures are dull, grey, mostly very blurred, and diffuse. Their presence is the horror and the hard-to-bear refusal to answer, to explain, to give an opinion. ${ }^{20}$

There is considerable art criticism debate around the series, most of which attempts to 'fix' the blur by providing often speculative context as if, argues Feldman, 'art theory had to restore the very event history, transparency, precision, and normativity that Richter eschewed both politically and aesthetically. ${ }^{21}$ While most try to re-anchor the work in a positivist history, one critic, Gertrud Koch, does the opposite and insists that the blurring 'is both subjective act and objective state at one and the same time'. She goes on, 'the relation to the world of objects blurs and the act of blurring causes that world...to appear as an impenetrable presence'. It is a 'vertigo as a way of relating to the object world. For Richter, she argues, 'It is not simply a case of imprecision; rather it is the capture of a sliding glance.22 This opens up another way of seeing that is not clear and stable. While Richter speaks of the 'horror' of the unanswered here, with reference to the fuzzing of the outlines, it is not the same as the horror described by Talal Asad with reference to formlessness itself. ${ }^{23}$ There is still form here, but it has been besmirched, destabilised and called into question.

For many who have tried to document and/or narrate the student protests in South Africa from 2015, causation, event-ness, violence, reason, contingency and effect are generative of hundreds of tangled and contentious accounts. In short, there is great messiness and much disagreement. The adoption of clarity in photographic and other visual documentation tends to underplay or override that messiness, doubtless including my own photographic images that accompany this text. At times this cohesive visual discourse has been marshalled in ways that seek to present one unified account or another, some of them strikingly polarised in their evidentiary positionings. Part of the drive to clarity has been the urgency and the speed at which things unfolded at the time. Besides closer scrutiny of what is there in terms of documentation, what might be needed now is further development of what has been emerging in the debates around artistic practice: more aesthetic range, latitude for experimentation, and a valorisation of the visual blur as a suggestive way to reflect upon the blurred sensations and experiences of what everyone saw and felt, and continues to feel. That is why I wish to share Wilton Schereka's experimentation with photographic blurring in the course of a project at UWC where students were enjoined to turn the camera dial away from Automatic. ${ }^{24}$

\footnotetext{
In ibid., 57.

Ibid.

Gertrud Koch, 'The Richter-Scale of Blur', October, 62 (Autumn 1992), 136. Cited in Feldman, Archives of the Insensible, 59.

Talal Asad, On Suicide Bombing (New York: Columbia University Press, 2007), 73.

The final two images in this essay are reproduced with kind permission of Wilton Schereka. Both were taken on the UWC campus grounds in 2016.
} 


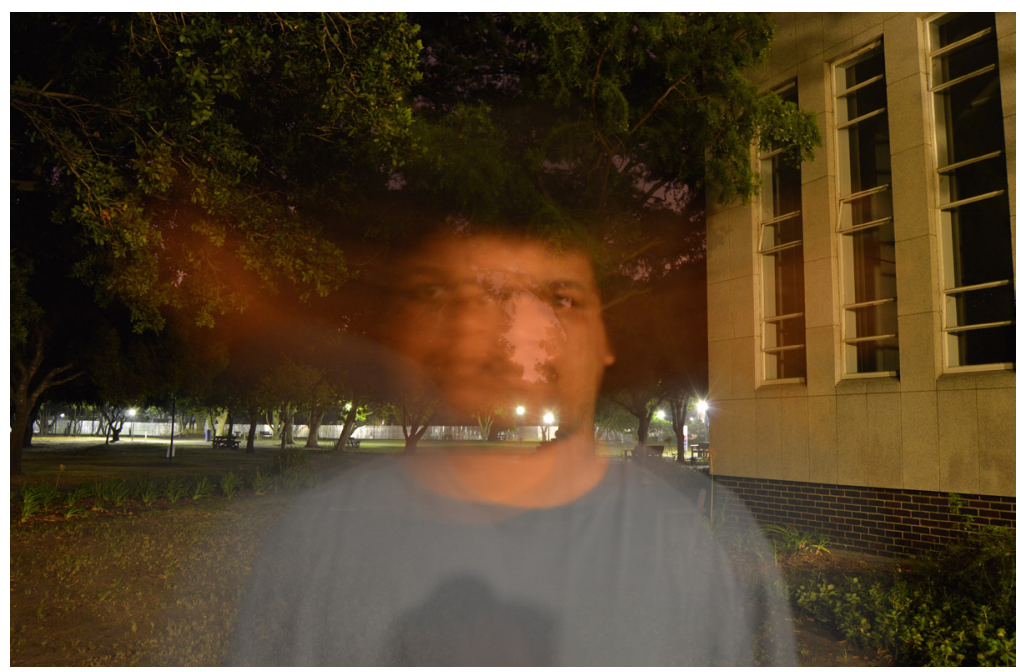

Figure 13

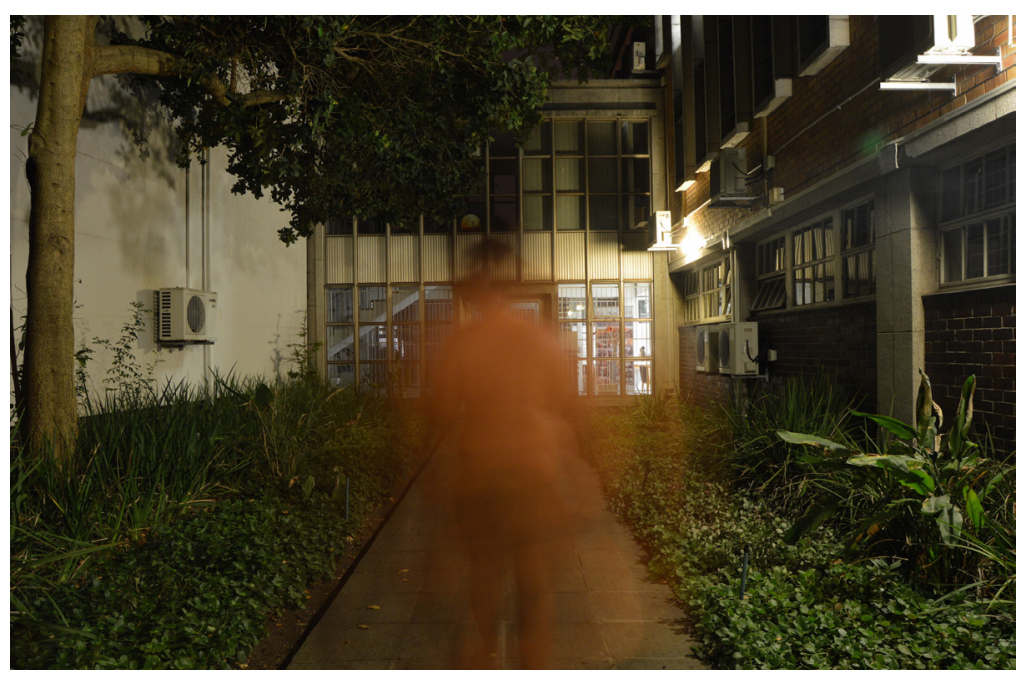

Figure 14

This series works with slow shutter speeds and other techniques for reducing the density and sharpness of the subject. It is described by Schereka as a way to express his sense of erasure as a student after the 2015 protests became more diffused, even as the problems continued and deepened. Blur is also created by movement. It is produced by the deliberate mismatch of motion or presence before the camera and the latter's technical capacities which on another shutter-speed setting would freeze a sharp and static image of the moving form. Clarity is therefore possible but eschewed. In its modest way the technique draws attention to the issue of time. With human movement and non-automatic technical response out of joint, it is a small reminder of the confused and multiple temporalities of protest and responses to it in the university. 
Photodynamic experimentation has a considerable history. In the 1910s the Bragaglia brothers used blur as a metaphor for modernity, believing it could recreate in a photograph the effects of movement on the human psyche. ${ }^{25}$ For Alexander Rodchenko and László Moholy-Nagy, movement could be used to cast figures into illegibility. This highlighted the 'transitory nature of the present', and how photography 'sustains the illusion of what we call "now"'. ${ }^{26}$ For both Richter and W.G. Sebald, photographic blur works as a metaphor for unstable memory, and photography's own failure to 'represent the inexpressible. ${ }^{27}$ The blur appears to destabilise the normative boundaries and centredness of the subject. It is also a stain on the taken-for-granted reputation for visual exposition of the present that is then ostensibly immediately past. Instead, questions keep piling up. The photographs arguably gesture towards the blurred sensations of those present as time seemed to increase its speed when the legitimacy of the university was called into question.

25 Marta Braun, 'Movement in Photography' in Robin Lenman, ed., The Oxford Companion to the Photograph (Oxford: Oxford University Press, 2005), 427. 